\title{
THE SPECIES OF Notiobia PERTY (COLEOPTERA: CARABIDAE: HARPALINI) FROM BRAZIL
}

\author{
Erik ARNDT
}

\begin{abstract}
The new species Notiobia glabrata, N. maxima and N. pseudolimbipennis are described. A key to the 1 I Notiobia (s.str.) species known from Brazil, data about the distribution of each species and taxonomical remarks are provided. Notiobia parilis Bates, 1878 is a junior synonym of $N$. nebrioides Perty, 1830 , and Notiobia umbrata Bates, 1882 is a junior synonym of $N$. flavicinctus Erichson, 1847. The Brazilian Notiobia species belong to at least three different species groups, each distributed from Brazil over the North-Western part of South America, Central America to Mexico.
\end{abstract}

Key words: Coleoptera, Carabidae, new species, Brazil.

As Espécies de Notiobia Perty (Coleoptera: Carabidae: Harpalini) do Brasil.

RESUMO - As novas espécies Notiobia glabrata, N. maxima e N. pseudolimbipennis são descritas. São fornecidos uma chave para as onze espécies de Notiobia (s. str.) conhecidas para o Brasil, dados sobre a distribuição e caracteristicas taxonômicas de cada espécie. Notiobia parilis Bates, 1878 é uma siinonimia de N. nebrioides Perty, 1830, e Notiobia umbrata Bates, 1882 é uma sinonimia N. Javicinctus Erichson, 1847. As espécies de Notiobia do Brasil pertencem a pelo menos três diferentes grupos de espécies, cada um distribuido do Brasil para a parte Noroeste da América do Sul, e da America Central até o México.

Palavras-chave: Coleoptera, Carabidae, espécies novas, Brasil

\section{INTRODUCTION}

The genus Notiobia Perty is part of the Anisodactylina, a subtribe of the large carabid tribe Harpalini. Noonan (1973) placed in Notiobia four groups previously regarded as separate genera: Diatypus Murray from the tropical region of Africa; Diaphoromerus Chaudoir from Australia, New Zealand, New Guinea, New Caledonia, the Moluccas, Timor, and Hawaii; Anisotarsus Chaudoir from North, Central, and temperate areas of South America; and Notiobia (s.str.) from Central America and tropical areas of South America.

The Neotropical species of the subgenus Anisotarsus were revised by Noonan (1981). Only two species are reported to occur in the dry areas of Brazil. The Mexican species of Notiobia (s.str.) were already revised in Noonan's (1973) classification of Anisodactylina. Much less is known about the taxonomy and distribution of Notiobia (s.str.) in areas south of Mexico.

The idea to describe and key out the Brazilian species of Notiobia (s.str) was born during an ecological study. Contrary to the rather strong taxonomical confusion of species in the mountain areas of Panama, Colombia, and Ecuador, the taxonomy of Brazilian species is quite clear. The present paper provides accurate taxonomic names for current ecological studies and provides information useful for future revision of all Notiobia species.

As far as known, Notiobia species live in forests. Adults of all species can fly. They are spermatophagous and their

Anhalt University of Applied Sciences, LOEL, Strentzfelder Allee 28, D-06406 Bemburg, Germany. 
larvae seem to develop only on specific fruits. Therefore, fruit fall events in the forests which are restricted in time and space cause complicated ecological adaptations of Notiobia species (Paarmann, pers. comm.). The results on the phylogenetic and zoogeographic relations of these species will help to understand the process of the ecological adaptations.

\section{MATERIAL}

Beside the vast material collected during an ecological research project by W. Paarmann, J. Adis and co-workers, and the author between 1992 and 1996, specimens of following institute collections were considered:

CAS - Dept, of Entomology, California Academy of Sciences (D. Kavanaugh, Berkeley, USA)

DEI - Deutsches Entomologisches Institut (L. Zerche, Eberswalde, Germany)

INPA - Instituto Nacional de Pesquisas da Amazônia (C.R.V. da Fonseca, Manaus, Brazil)

MPM - Milwaukee Public Museum (G.R. Noonan, Milwaukee, USA) MZUSP - Museu de Zoologia da Universidade São Paulo (C. Costa, São Paulo, Brazil)

NMNH - National Museum of Natural History/Smithsonian Institute (M. Pogue \& T.L. Erwin, Washington USA)

RSNB - Institut Royal des Sciences Naturelles de Belgique (J. Cools \& K. Desender, Bruxelles, Belgium)

ZMB - Zoologisches Museum der Humboldt-Universität (F. Hieke, Berlin, Germany)

ZSS - Zoologische Staatssammlung (M. Baehr, Munich, Germany)

The terminology of the descriptions and key follows Noonan $(1981,1991)$.

\section{DESCRIPTIONS}

\section{Generic characters of Notiobia (s.str.)}

Body length: 7-15 mm; body form slender to moderately stout.

Color: Dorsum testaceous, green, blue-green, cupreous or black with or without metallic lustre; ventral side generally dark piceous; legs, palps and antennomeres testaceous or piceous.

Head: Labrum straight to emarginate anteriorly; clypeus broadly emarginate; mentum with prominent median tooth, mentum and submentum completely separated by a transverse suture; paraglossa slightly longer than ligula. Frons usually with moderate to prominent fovea bearing a clypeo-ocular prolongation. Eyes mostly large and protruding; width of narrowest part of gena less than maximum width of antennomere I; supraantennal ridges divergent anteriorly.

Thorax: Pronotum arcuate anteriorly, convergent posteriorly; posterior angles rounded or distinct, base lobed in most species; basal fovea more or less distinct; lateral bead complete, basal and anterior bead at least laterally distinct.

Legs: Anterior tibia with apical spur lanceolate; posterior femur usually with 2 long setae on posterior margin; posterior tarsus with segment I shorter than II+III; anterior and middle tarsi of males moderately to very strong enlarged.

Elytra: Interval III with a setigerous puncture in apical third; interval VII with a small setigerous puncture near apex and a slightly more proximal ocellate puncture. Hind wings 
fully developed in most specimens.

Abdomen : Sternum VI of males with a pair of ambulatory setae. Median lobe of aedeagus symmetrical, without apical disc. Valvifer flat to slightly convex, lateral margin semi-membranous and without distinct boundary.

\section{Notiobia (s.str.) pseudolimbipennis}

\section{sp. n.}

(Figs. 1, 4, 5, 6, 20)

Holotype: Male. Brazil, AM, Reserva Florestal A. Ducke, $35 \mathrm{~km}$ NE Manaus, $31.08 .93 \mathrm{leg}$. Paarmann et al. 55 paratypes ( 23 males, 32 females) from the same locality and collector. 6 males, 4 females $31.08 .93,3$ males, 9 females 08.02.93, 2 males, 4 females 06.07.94, 5 males, 2 females 11.07.94, 1 female 7 . and $11.08 .95,1$ male, 1 female $22.08 .95,6$ females 23.08.95, 1 female $16.09 .95,4$ males, 4 females 29.10.95, 2 males 20.05.96.

Body length: $11-13 \mathrm{~mm}$.

Color: Dorsum with labrum rufopiceous and clypeus yellow-piceous; remaining parts of head, pronotum, and elytra greenish, bluegreen or cupreous with metallic lustre; ventral part of body generally dark piceous; legs rufopiceous to dark rufopiceous, palpi and antenna testaceous.

Head: Labrum straight anteriorly, clypeus broadly emarginate anteriorly; frons with foveae punctiform, bearing a distinct clypeo-ocular prolongation to eyes; eyes large and protruding. Microsculpture not distinct, micropunctures present.

Thorax: Pronotum with sides arcuate anteriorly, convergent and rectilinear posteriorly; posterior angles arcuate to slightly obtuse, base lobed; lateral depression complete, widened posteriorly and ending in the wide, shallow basal fovea; lateral bead complete, basal and anterior beads only distinct at the sides, absent in the middle. Microsculpture of very fine transverse meshes, micropunctures present.

Legs: Dorsa of all tarsi glabrous except the anterior tarsi I-IV of males which bear single small hairs. Anterior and median tarsi of males strongly expanded laterally.

Elytra: Scutellar striae moderately long, posteriorly turning to stria I; intervals slightly convex, subapical sinuation distinct (Fig. 1); sutural angles broadly rounded. Elytral intervals with micropunctures, microsculpture of inner intervals fine transverse meshes, that of lateral 2-3 intervals strongly granulate.

Abdomen: Sternum VI of females evenly rounded apically (Fig. 4). Aedeagus with median lobe slender with pointed apex (Figs. 5, 6). Everted internal sac (Fig. 20) with a large field of macrotrichia on right side.

Distribution: The species is known from the type locality and from Panama, Cerro Campana.

Derivation of species name: The name expresses the similarity of the new species to $N$. viridula ( $=N$. limbipennis).

Deposition of type material: The holotype and part of the paratypes are deposited at the Systematic Entomology collection of the INPA (Manaus, Brazil). The rest of the paratypes are at the Zoological Museum of the University São Paulo, in the collection W. Paarmann and the collection of the author.

Discussion: N. pseudolimbipennis is closely related to $N$. viridula, a widespread 
species in Central and South America. However, N. pseudolimbipennis is clearly distinguished from $N$. viridula by the lack of the apical spine of sternum VI in females. Furthermore, the granulate lateral area of the elytra is green or green-bronze with a metallic lustre like the rest of the elytral intervals in the Brazilian specimens of $N$. pseudolimbipennis. It is distinctly lighter, yellow-testaceous in $N$. viridula.

$N$. viridula is not known from the Amazonian lowlands. Probably $N$. pseudolimbipennis replaces $N$. viridula in this region.

Specimens without an apical spine on sternum VI of females but with bicolored elytra were found in Panama (Cerro Campana, coll. NMNH). These specimens have a green-bronze dorsal surface, but the granulate area is not extended like in $N$. viridula. Therefore these Panamanian specimens belong to $N$. pseudolimbipennis but represent a transitional form which is similar to $N$. viridula.

\section{Notiobia (s.str.) glabrata sp.n.}

(Figs. 2, 15, 16, 22, 23)

Holotype: Male. Brazil, AM, Reserva Florestal Ducke, $35 \mathrm{~km}$ NE Manaus. 20.04.93 leg. Paarmann et al. 35 paratypes ( 21 males, 14 females) from the same locality and collector. 2 males, 2 females 20.04.93, 1 male, 1 female $09.06 .92,4$ males, 2 females 14.02.93, 2 males, 1 male $26.05 .94,2$ males, 2 females $20.06 .94,1$ female 25.06.94, 1 male, 1 female 24.07.94, 1 male, 3 females 05.07.94, 2 males, 1 female $08.07 .94,1$ male $29.10 .95,5$ males 20.05.96.

Body length: 10-12 mm.
Color: Dorsum with labrum and clypeus piceous; remaining parts of head, pronotum, and elytra green or cupreous with metallic lustre; ventral part of body generally dark piceous; legs piceous, palpi and antenna yellow-piceous.

Head: Labrum straight to slightly emarginate anteriorly, clypeus broadly emarginate anteriorly; frons with foveae punctiform, bearing a distinct clypeo-ocular prolongation to eyes; eyes large and protruding. Microsculpture not distinct, micropunctures present.

Thorax: Pronotum (Fig. 23) with sides arcuate anteriorly, convergent and rectilinear posteriorly; posterior angles distinct, not rounded, slightly obtuse, base lobed; lateral depression complete; basal fovea shallow; basal and lateral beads complete; anterior bead distinct only at the sides, obsolete in the middle. Microsculpture not distinct, surface shining; micropunctures present.

Legs: Dorsa of anterior tarsi I-IV of males pubescent, rest of tarsi of males and tarsi of females glabrous dorsally; anterior and median tarsi of males comparably slightly extended.

Elytra: Scutellar striae moderately long and not reaching stria $\mathrm{I}$; intervals slightly convex; subapical sinuation of elytra not distinct (Fig. 2); sutural angles broadly rounded. Microsculpture lacking even in lateral intervals, elytra shining; micropunctures present.

Abdomen: Sternum VI of females evenly rounded apically (cf. Fig. 4), Aedeagus with median lobe obtusely rounded apically (Figs. 15, 16). Everted internal sac (Fig. 22) dorsobasally with a field of 5-25 large spines. The spines are arranged more 
or less in two rows.

Distribution: The species is known from the type locality and from Peru, prov. Loreto, Rio Napo, Rio Amazonas, prov. Madre de Dios, Pakitza, Guyana, and Bolivia, prov. La Paz (one specimen each in NMNH and MPM).

Derivation of species name: The name is related to the dorsal surface of the body which lacks a microsculpture.

Deposition of type material: The holotype and part of the paratypes are deposited at the Systematic Entomology collection of the INPA (Manaus, Brazil). The rest of the paratypes are at the Zoological Museum of the University São Paulo, in the collection W. Paarmann and the collection of the author.

Discussion; $N$. glabrata is morphologically a transitional form between $N$. leiroides and $N$. maxima. $N$. glabrata differs from $N$. maxima by the structure of the aedeagus and the generally smaller size. $N$. glabrata is distinguished from $N$. leiroides by the distinctly slender anterior tarsi of males and the absence of microsculpture. Moreover, the typical $N$. leiroides lacks a prolongation of the frontal foveae to the eyes. However there are known specimens of the leiroides-group from Peru with a clypeo-ocular prolongation of the frontal fovea and with flattened microsculpture, which are close to $N$. glabrata. Further studies are needed to decide if these specimens fall within the variation of $N$. leiroides or represent a separate species. A rather strong radiation of this groups occurs also in Panama. A revision of the Panamanian forms is needed.

\section{Notiobia (s.str.) maxima sp.n.}

(Figs. 13, 14, 21)

Holotype: Male. Brazil, AM, Reserva Florestal A. Ducke, $35 \mathrm{~km}$ NE Manaus. 17.08 .92 leg. Paarmann et al. 20 paratypes (12 males, 8 females) from the same locality and collector. 1 female $17.08 .92,1$ male 20.10.93, $15.11 .93,14.12 .93,26.05 .94,1$ male, 2 females $20.06 .94,1$ male, 2 females 22.06.94, 1 female 05.07.94, 11.07.94, 1 male 8.07.94, 24.07.94, 10.01.95, 1 female 20.12.95, 3 males 20.05.96.

Body length: $13-15 \mathrm{~mm}$.

Color: Dorsum with labrum and clypeus piceous; remaining parts of head, pronotum, and elytra green, bronze or cupreous with metallic lustre; ventral part of body generally dark piceous; legs, palpi and antenna piceous.

Head: Labrum slightly emarginate anteriorly, clypeus broadly emarginate anteriorly; frons with foveae punctiform, bearing a distinct clypeoocular prolongation to eyes; eyes large and protruding. Microsculpture not distinct, micropunctures present.

Thorax: Pronotum (Fig. 23) with sides arcuate anteriorly, convergent and rectilinear posteriorly; posterior angles arcuate to slightly obtuse, base lobed; lateral depression complete, ending in shallow basal fovea; basal and lateral beads complete; anterior bead distinct only at sides, obsolete in middle. Microsculpture not distinct, surface shining; micropunctures present.

Legs: Dorsa of anterior tarsi I-IV in males with single fine hairs, rest of tarsi in males and tarsi in females gla- 
brous dorsally; anterior and median tarsi of males usually expanded laterally.

Elytra: Scutellar stria moderately long and nearly reaching stria I; intervals slightly convex; subapical sinuations of elytra not distinct (Fig. $2)$; sutural angles broadly rounded. Microsculpture lacking even on lateral intervals, elytra shining; micropunctures present.

Abdomen: Sternum VI of females evenly rounded apically (Fig. 4). Aedeagus with median lobe obtusely rounded apically (Figs. 13, 14). Everted internal sac (Fig. 21) with irregularly distributed large spines.

Distribution: The species is only known from the type locality.

Derivation of species name: The name refers to the body size, it is the largest knc.wn species of Notiobia (s.str.).

Deposition of type material: The holotype and part of the paratypes are deposited at the Systematic Entomology collection of the INPA (Manaus, Brazil). The rest of the paratypes are at the Zoological Museum of the University São Paulo, in the collection W. Paarmann and the collection of the author.

\section{Checklist of Notiobia (s. str.) Perty}

(Underlined species are known from Brazil.)

aulica (Dejean, 1829: 295) (Distribution: Brazil, states Rio Grande do Sul, São Paulo, Santa Catarina, Rio de Janeiro, Parana, Espirito Santo, Goiás, Mato Grosso do Sul, Pará, Amazonas; Paraguay, Asunción; Argentina, provs. La Rioja, Salta; Colombia; Ecuador, Baños; Bolivia, depts. Cochabamba, Carrasco; Peru, depts. Madre de Dios,
Pakitza; Venezuela, states Merida, Aragua. Remarks: Described as Harpalus aulicus. Separation from wilkensi Chaudoir difficult, especially in females.)

chiriquensis Bates, 1884: 270 (Distribution: Panama, Volcano de Chiriqui; Bolivia, Yungas, Incachaca $2100 \mathrm{~m}$, Cochabamba. Remarks: Synonym concolor Bates nec Putzeys.)

concolor Putzeys, 1878: 72 (Distribution: Colombia, divs. Cundinamarca, Caldas, Norte de Santander.)

cooperi Noonan, 1973: 325 (Distribution: Mexico, states Nayarit, Tepic.)

cupreola Bates, 1878: 590 (Distribution: Costa Rica, Irazu.)

disparilis Bates, 1878: 589 (Distribution: Brazil, states São Paulo, Amazonas; Bolivia, dept. Cochabamba; Peru, depts. Loreto, Madre de Dios; Suriname, Marowijne distr.; French Guiana, Rio Lawa; Nicaragua; Panama, Canal Zone, Barro Colorado Isl.)

ewarti Noonan, 1973: 325 (Distribution: Mexico, states Veracruz, Chiapas.)

flavicinctus Erichson, 1847: 70 (Distribution: Brazil, states Sat Paulo, Amazonas; Bolivia, dept. Cochabamba; Peru, depts. Madre des Dios, Loreto; Guatemala; Panama, Canal Zone, Barro Colorado Isl.; southern Mexico. Remarks: Described as Anisotarsus flavicinctus; synonym: umbrata Bates, 1882. The type series of $N$. flavinctus in the ZMB collection is conspecific with the species described by Bates. The range of variation in this widespread species is comparatively low.) glabrata Arndt, sp. n. (Distribution: Brazil, state Amazonas; Peru, 
depts. Loreto, Madre des Dios; Bolivia, dept. La Paz; Guyana.)

incerta Bates, 1882: 53 (Distribution: Nicaragua. Remarks: $N$. incerta is probably a synonym of $N$. umbrifera Bates (G. Noonan, pers. comm.; G. Noonan compared both types in the collection of the British Natural History Museum.)

jucunda Putzeys, 1878:71 (Distribution: Brazil, state Bahia; Venezuela, state Zulia; Colombia, div. Cundinamarca; Ecuador, prov. Tungurahua. Remarks: A single specimen is probably known from Brazil. It is deposited in the collection of ZMB and labeled "Bahia" which means probably the Brazilian state).

leiroides Bates, 1878: 590 (Distribution: Panama, Cerro Campana, Canal Zone, Barro Colorado Isl.; El Salvador, Depto. La Liberdade; Nicaragua; Guatemala; British Honduras; Mexico; Texas)

longipennis Putzeys, 1878: 73 (Distribution: Colombia, between Tapias and Las Cruzes.)

maxima Arndt, sp. n. (Distribution: Brazil, state Amazonas.)

melaena Bates, 1882: 54 (Distribution: Guatemala; Mexico.)

nebrioides Perty, 1830: 13 (Distribution: Brazil, states São Paulo, Amazonas, Goiás; Bolivia, depts. Cochabamba, Santa Cruz, Pando; Peru, depts. Junin, Madre de Dios, Loreto; Ecuador, Esmeraldas; Trinidad; Panama, Canal Zone, Barro Colorado Isl.; Costa Rica, Turrialba, Reventazón riv.; southern Mexico. Remarks: Synonyms: brasiliensis Chaudoir 1835, parilis Bates, 1878. N. nebrioides was described based on a single specimen from "Brasilia australis". The holotype is deposited in the collection of ZSS. This specimen falls within the variation range of the variable species $N$. parilis Bates, 1878. Therefore, $N$. parilis Bates is a junior synonym of $N$. nebrioides. For further remarks see $N$. parilis in Noonan 1973.)

obscura Bates, 1882: 53 (Distribution: Southern Mexico. Remarks: Synonym virens Bates 1882, Noonan 1973.)

pallipes Bates, 1882: 53 (Distribution: Trinidad; Panama; Guatemala; Costa Rica; southern Mexico. Remarks: Probably conspecific with aulica Dejean; synonym: subaurata Bates 1882, Noonan 1973.)

pseudolimbipennis Arndt, sp. n. (Distribution: Brazil, state Amazonas; Panama, Cerro Campana.)

ruficnuris (Brulli, 1838: 35) (Distribution: Bolivia.)

similis Putzeys, 1878: 72 (Distribution: Colombia, Ubáque, Manizales.)

umbrifera Bates, 1884: 271 (Distribution: Brazil, states São Paulo, Rio de Janeiro, Goiás, Rio Grande do Sul, Amazonas, "Upper Amazonas"; Peru, depts. Loreto, Madre des Dios; Panama, Canal Zone, Barro Colorado Isl.)

viridula (Dejean, 1829: 297) (Distribution: Brazil, states Santa Catarina, Parana, Curitiba, Rio de Janeiro; Peru, depts. Loreto, Madre de Dios; Bolivia, dept. Cochabamba; Trinidad; Tobago; French Guiana, St. Laurent du Maroni; Costa Rica, Turrialba, Reventazón riv.; Panama, Canal Zone, Barro Colorado Is!. El Salvador, San Salvador; Nicaragua; Guatemala, dept. Zacapa; Mexico. 
Remarks: Described as Harpalus viridulus; synonyms: limbipennis Bates, 1878; sinuessa Bates, 1882; viridella Csiki. $N$. limbipennis is a junior synonym of $N$. viridula, G. Noonan (pers. comm.) who examined the holotype in the Museum National d'Histoire Naturelle Paris, confirmed van Emden's determination of this species in several museum collections.)

wilkensi (Chaudoir, 1837: 47) (Distribution: Brazil, states Espirito Santo, Santa Catarina; Paraguay, Alto Parana; Argentina, Rio Salado. Remarks: Described as Harpalus wilkensi.)

Three undescribed species are not included in the list: two species similar to $N$. nebrioides (from Bolivia, dept. Cochabamba; Peru, depts. Madre de Dios, Loreto), and one species similar to $N$. jucunda (from Bolivia, Cochabamba and Argentina, Salta-distr.).

The taxonomy of the jucundal chiriquenisis-group from Panama, Chiriqui needs a revision.

\section{Junior synonyms}

aequata Bates, 1882: 54 (synonym of melaena Bates).

brasiliensis Chaudoir, 1835: 431 (synonym of nebroides Perty).

championi Bates, 1882: 54 (synonym of jucunda Putzeys).

concolor Bates, 1882: 53 non Putzeys (synonym of chiriquensis Bates).

limbipennis Bates, 1878: 590 (synonym of viridula (Dejean).

parilis Bates, 1878: 590 (synonym of nebrioides Perty).

sinuessa Bates, 1882: 56 (synonym of limbipennis Bates).

subaurata Bates 1882: 53 (syn- onym of pallipes Bates).

umbrata Bates, 1882: 55 (synonym of flavicinctus Erichson).

virens Bates 1882: 53 (synonym of obscura Bates).

viridella Csiki, 1929: 1047 (synonym of viridula (Dejean).

\section{Transferred species}

Notiobia praeclara Putzeys, 1878 was transferred to Anisotarsus Chaudoir by Noonan (1981).

Notiobia transversicollis Putzeys, 1878 and columbiana Reiche, 1843 are members of the subtribe Pelmatellina (confirmed by G. Noonan, pers. comm.). N. colombiana was described as Acupalpus and transferred to Notiobia by Putzeys (1878). According to the description, $N$. aeneola Putzeys, 1878 and dubia Putzeys, 1878 are also Pelmatellina, however, the types were not available.

\section{DISCUSSION}

The 11 species known from Brazil can be tentatively placed in 3 species groups.

The first group is characterized by granulate lateral areas of the elytra, which are in part light yellow-testaceous. This character is absent in Anisotarsus and related genera and can be considered as apomorphic. The group includes the species Notiobia disparilis, $N$. nebrioides, $N$. pseudolimbipennis, $N$. viridula, and probably $N$. flavicinctus. All these species occur on fallen fruits of Ficus. The larval development of $N$. pseudolimbipennis and $N$. flavicinctus was also observed on fallen fruits of Ficus. However, the $N$, nebrioides population of Manaus (Brazil) was found 
to develop on fallen fruits of Vismia and Coussapoa (Paarmann, pers. comm.), and one of the populations in Loreto Boca (Peru) was collected on fallen fruits of Cecropia (specimens in NMNH). $N$. nebrioides is the species with the weakest development of the granulate microsculpture.

The second group has flat elytral intervals, the microsculpture is uniform or absent. These characters are probably plesiomorphic (see also Noonan 1973). The phylogenetic relationship of the species is therefore not evident. The group includes $N$. aulica, N. glabrata, $N$. jucunda, N. maxima, and $N$. wilkensi. The larval development of these species was observed on fallen fruits of Melastomataceae or (in Peru) Cecropia. The adults also appear on fallen fruits of Ficus, where they only eat but do not reproduce (Paarmann, pers. comm.).

The third group comprises only N. umbrifera, which cannot be placed in one of the previous groups. This species has a spatula-shaped prolongation of the median lobe of the aedeagus, which is doubtless an apomorphic character state. Adults of N. umbrifera were frequently found on Ficus, Cecropia and on Miconia fruit fall. The larval development was only observed on Miconia fruit fall (Paarmann, pers. comm.).

All three species groups are widespread and occur in the whole area of Notiobia (s.str.) from Brazil to Mexico.

KEYS TO THE SUBGENERA AND SPECIES

Key to the subgenera Notiobia (s.str.) Perty and Anisotarsus

\section{Chaudoir (after Noonan 1973).}

1 Gena narrow, narrower than maximum width of antennomere I or frontal fovea with clypeo-ocular prolongation; eyes mostly strongly protruding. 2

- Gena wide, wider than maximum width of antennomere I; eyes not protruding. Anisotarsus

2(1) Frontal fovea with clypeo-ocular prolongation. Notiobia (s.str.)

- Frontal fovea without clypeo-ocular prolongation. 3

3(4) Frontal fovea of head large, prominent; supra-antennal ridges strongly divergent anteriorly from eyes; eyes large and protruding. Notiobia (s.str.)

-Frontal fovea of head small, supraantennal ridges various, size of eyes various. Anisotarsus

\section{Key to the Notiobia (s.str.) species from Brazil}

1 Postero-lateral intervals of elytra with a region of distinct granulate microsculpture, extended in some females to widest part of the elytra and/or light yellowish; subapical sinuation of elytra prominent (Fig. 1) or not (Fig. 2).

- Lateral intervals of elytra without granulate microsculpture; microsculpture of all intervals uniform or lacking; lateral parts of elytra not yellowish and not lighter than the green colored inner intervals; subapical sinuation of elytra not prominent (Fig. 2), 7

2(1) Subapical sinuation of elytra prominent (Fig. 1).

- Subapical sinuation of elytra not prominent (Fig. 2). 5

$3(2)$ Intervals of elytra the same in males and females, not convex; 
median lobe of aedeagus various; dorsum green, bronze or blue-green, lateral intervals in part pale yellow-testaceous.

- Males with intervals of elytra convex, dorsum of males bicolored in most specimens, head and pronotum golden green-cupreous, elytra black with purple tinge; median lobe of aedeagus with short but wide apex (Fig. 7). Females with convex intervals 2,4 and 6 , but flat intervals $1,3,5$, and 7 ; dorsum of females uniformly dark colored. $N$. disparilis Bates

4(3) Sternum VI of females produced into a ventrally projected spine (Fig. 3 ); median lobe of male aedeagus with short but wide apex (Fig. 12); elytra distinctly bicolored, with lateral intervals granulate, pale yellow-testaceous and inner intervals green-cupreous; in females granulated area in the anterior part enlarged, covering the full anterior part of elytra. N. viridula (Dejean)

- Sternum VI of females rounded apically (Fig. 4); median lobe of male aedeagus with longer and more narrow apex (Figs. 5, 6); elytra not distinctly bicolored in most specimens; granulated area of elytra anteriorly not expanded to the middle part, dorsal surface more shining, green, cupreous or black with greenish, bluish or purple lustre.

N. pseudolimbipennis sp. $\mathrm{n}$.

5(2) Body length $11-13 \mathrm{~mm}$; lateral intervals of elytra of the same color as inner intervals, not pale yellow-testaceous; median lobe of aedeagus pointed (Fig. 8).. N. nebrioides Perty

- Body length 7-10 mm; lateral intervals, in some females whole elytra except a preapical macula, granulated and pale yellow-testaceous, inner intervals green or cupreous; aedeagus not as in Fig. 8.

6 (5) Pale region of lateral intervals in both sexes narrow, sometimes indistinct; body length usually $7-8 \mathrm{~mm}$; apex of median lobe of aedeagus elongated, spatula-shaped (Fig. 9, 10), anterior tarsi of males much narrower than in the following species.

N. umbrifera Bates

- Pale region of lateral intervals strongly enlarged in females, in specimens from the Andes and Central America covering the whole elytra except a subapical region, in Amazonian specimens extended to the lateral 4-5 intervals in the posterior part of elytra; median lobe of aedeagus very slender, with nearly rounded apex (Fig. 11); anterior tarsi of males very wide. N. flavicinctus (Erichson)

7 (1) Elytra very smooth and shining, microsculpture even in the outer intervals indistinct, intervals not completely flattened; posterior angles of pronotum not rounded, subdentate (Fig. 23). 8

- All intervals of elytra with equal and distinct microsculpture, elytra dull, intervals very flat, separate from each other only by a faint row of punctures; posterior angles of pronotum rounded (Figs. 24, 25).

8 (7) Body length $13-15 \mathrm{~mm}$; median lobe of aedeagus wide and stout (Figs. $13,14)$. N. maxima $\mathrm{sp} . \mathrm{n}$.

- Body length 10-12 mm; median lobe of aedeagus compareably slender (Figs. 15, 16). N. glabrata sp. $\mathrm{n}$.

9 (7) Posterior angles of pronotum rounded (Fig. 25); body parallel sided, body length $11-12.5 \mathrm{~mm}$; median lobe of aedeagus wide (Fig. 19).

N. jucunda Putzeys 
- Posterior angles of pronotum more distinct (Fig. 24); body shorter and stout, length $8-10 \mathrm{~mm}$.

10 (9) Median lobe of aedeagus slender with apex pointed (Fig. 17). .... N. aulica (Dejean)

- Median lobe of aedeagus very narrow with apex elongated but not pointed (Fig, 18) N. wilkensi (Chaudoir)

\section{ACKNOWLEDGEMENTS}

I wish to thank all colleagues who sent me collection material of Notiobia. I thank very much Prof. Dr. G. R. Noonan (MPM, Milwaukee) for his manifold support of my stay in Milwaukee, and for his comments to my MS. Furthermore, I thank very much Drs D. Judd, T, L. Erwin, M. Pogue and D. Polhemus for their generous help in Washington. I am indebted to Dr. J. Adis (MPIL, Plön), Dr. C. Costa (ZMUSP, São Paulo), Dr. C. Martius (INPA, Manaus), and Prof. Dr. W. Paarmann (Göttingen) for their support during my stay in Brazil. I am indebted to Dr. M. L. Luff (Newcastle u.T.) for the linguistic correction of the MS.

The study was supported by grant No. Ar 230/1-2 of the German Research Foundation (Deutsche Forschungsgemeinschaft).

\section{Literature cited}

Bates, H. W. 1878. On new genera and species of geodephagous Coleoptera from Central America. Proc. zool. Soc. London: 587-609.

Bates, H. W. 1882. Biologia Centrali-Americana, Insecta, Coleoptera, Carabidae, vol. I.: 40-152.

Bates, H. W. 1884. Biologia Centrali-Americana, Insecta, Coleoptera, Cicindelidae suppl.,
Carabidae suppl., vol. I.: 257-290.

Brullé, G. A. 1838. Insectes de l'Amérique méridionale recueillis par Alcide d'Orbigny. In: Voyage dans l'Amérique méridionale recueillis par Alcide d'Orbigny: 17-56.

Chaudoir, M. 1835. Description de quelques genres et espèces de carabiques nouveaux. Annls. Soc. ent. France, 4:429-448.

Chaudoir, M. 1837. Genres noveaux et especes nouvelles de coléoptères de la famille des carabiques. Moskovskoe Obschestvo Ispytatelei Prirody: 10:3-48.

Csiki, E. 1932: Coleopterorum Catalogus, pars 121. Carabidae: Harpalini VI, W. Junk. Berlin: 1023-1278.

Dejean, P. F. M. A. 1829. Spécies géneral des coléopréres de la collection de M. Le Comte Dejean. vol. 4. MéquignonMarvis. Paris. 520 p.

Erichson, W. F. 1847. Conspectus Insectorum Coleopteronum, quae in Republica Peruanan observata sunt. Arch. Naturgesch., 13:67-185

Noonan, G. R. 1973. The Anisodactylines (Insecta: Coleoptera: Carabidae: Harpalini): classification, evolution, and zoogeography. Quaestiones entomologicae, 9:266-480.

Noonan, G. R. 1981. South American species of the subgenus Anisotarsus Chaudoir (genus Notiobia Perty: Carabidae: Coleoptera), Part 1. Taxonomy and Natural History. Contributions in Biology and Geology, 1-84.

Noonan, G. R. 1991. Classification, Cladistics, and Natural History of Native North American Harpalus Latreille (Insecta: Coleoptera: Carabidae: Harpalini), Excluding Subgenera Glanodes and Pseudophonus. The Thomas Say Foundation XIII:1-310.

Perty, J. A. M. 1830. Insecta Brasiliensia. In. Martius, C.F.P.(ed.): Delectus animalium articulatorum. Fascicle 1. Monaco.:1-209.

Putzeys, M. J. 1878. Descriptions de carabides nouveaux de la Nouvelle Grenade. Mitt. Münch. Ent. Ver, 12:54-76.

Reiche, L. J. 1843. Coléoptères de Columbie. Revue Zoologique, 6:177-180. 

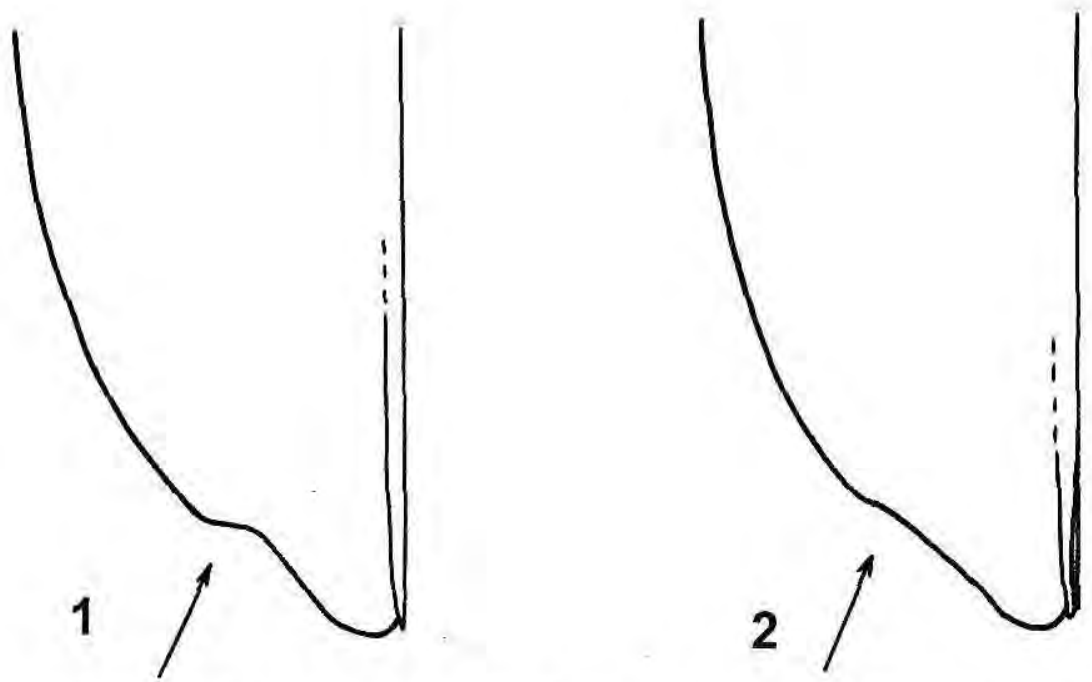

Figures 1-2. Subapical sinuation of elytra. Fig. 1. N. pseudolimbipennis. Fig. 2. N. glabrata.
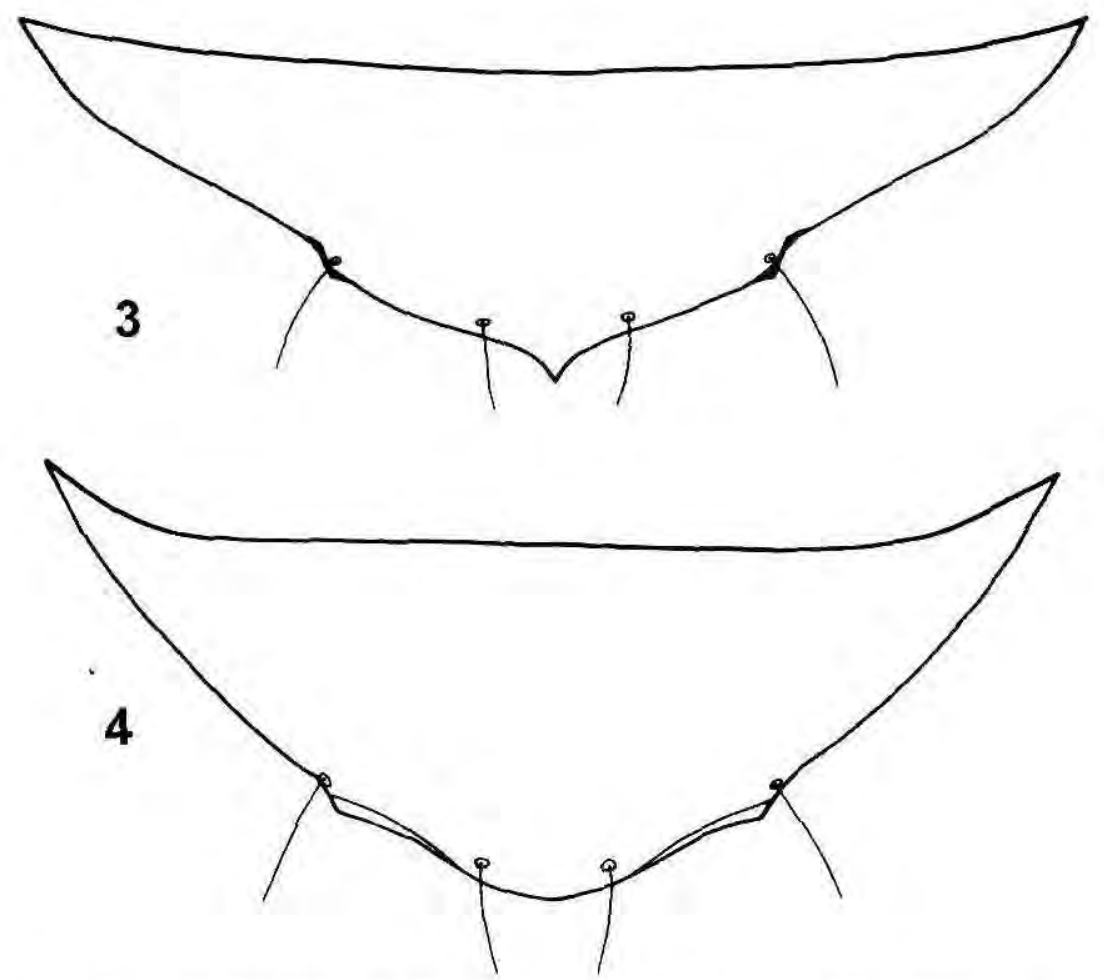

Figures 3-4. Sternite VI of female. Fig. 3. N. viridula. Fig. 4. N. pseudolimbipennis. 

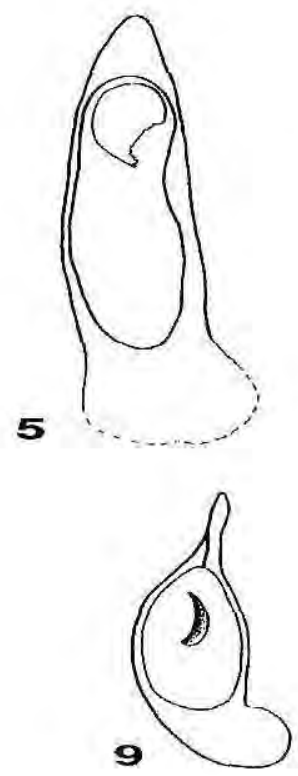

10
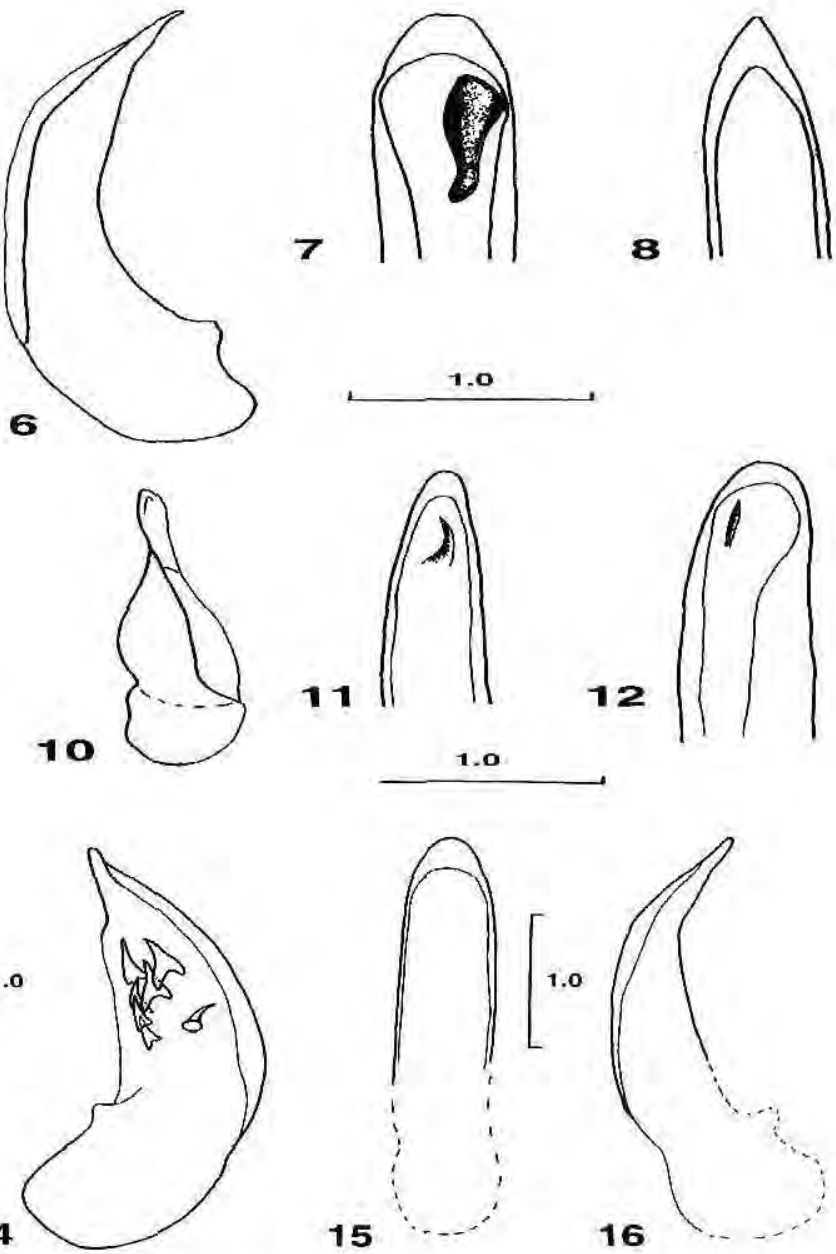

13

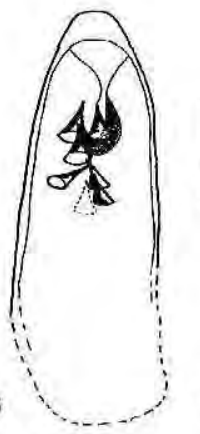

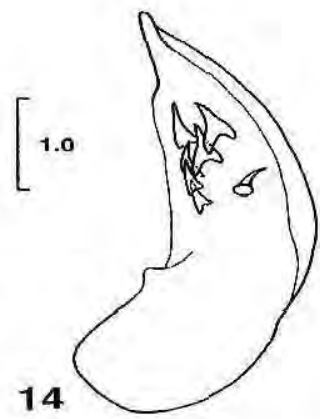

15

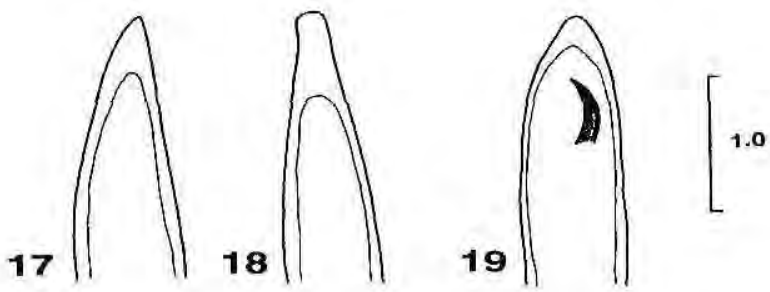

Figures 5-19. Median lobe of aedeagus. Figs. 5, 6. N. pseudolimbipennis, dorsal and lateral aspect, Fig. 7. $N$. disparilis dorsal aspect, Fig. 8. N. nebrioides, dorsal aspect, Figs. 9, 10. N. umbrifera, dorsal and lateral aspect, Fig. 11. N. flavicinctus, dorsal aspect, Fig. 12. N. viridula, dorsal aspect, Figs, 13, 14. N. maxima, dorsal and lateral aspect, Figs. 15, 16. N. glabrata, dorsal and lateral aspect, Fig. 17. N, aulica, dorsal aspect, Fig. 18. N. wilkensi, dorsal aspect, Fig. 19. N. jucunda, dorsal aspect (scales $1 \mathrm{~mm}$, only Figs. 13, 14 smaller scale). 

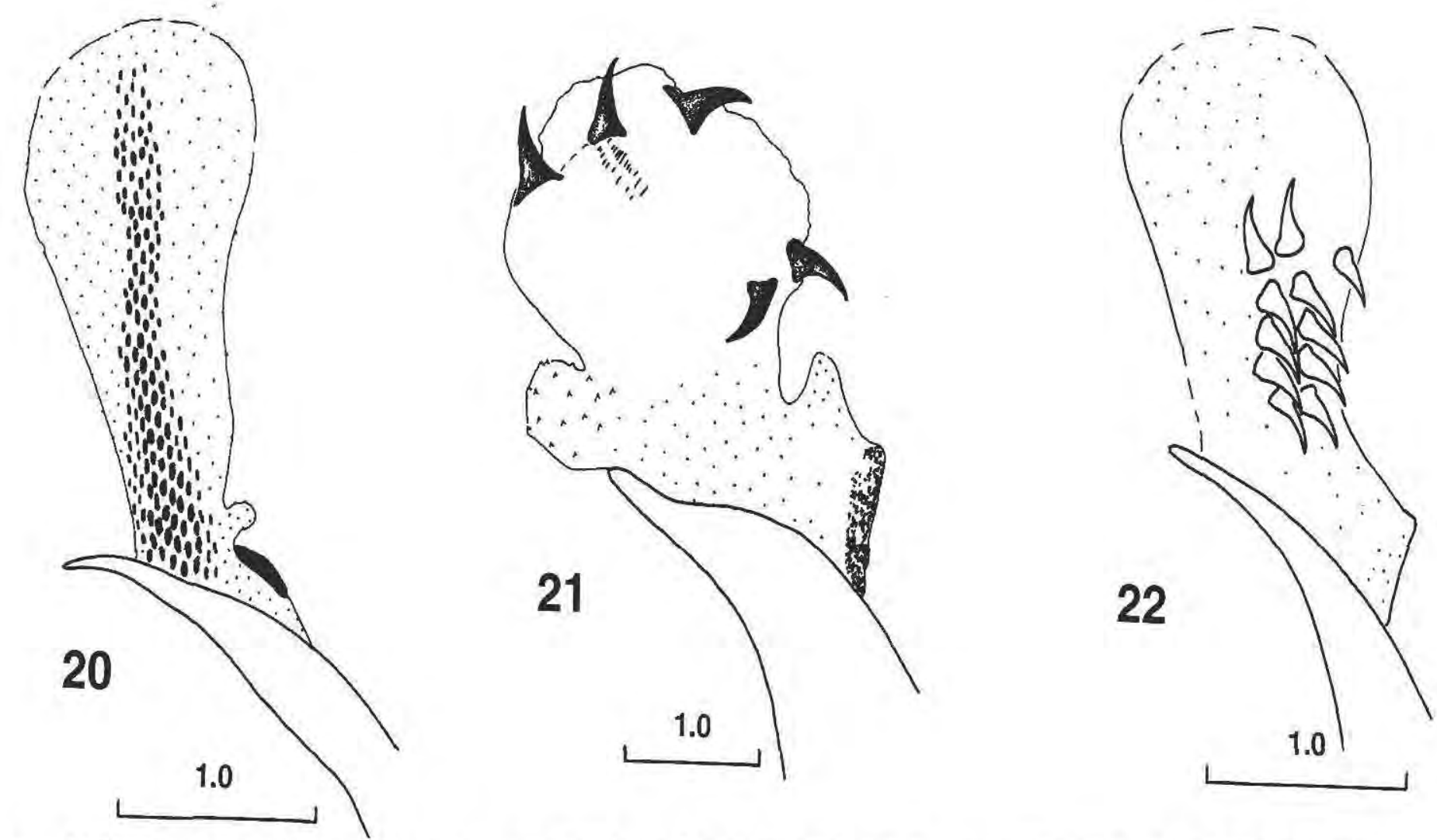

$\stackrel{?}{\mathrm{z}}$

Figures 20-22. Everted internal sac of male genitalia. Fig. 20. N. pseudolimbipennis, Fig. 21. N. maxima, Fig. 22. N. glabrata (scales 1 mm). 

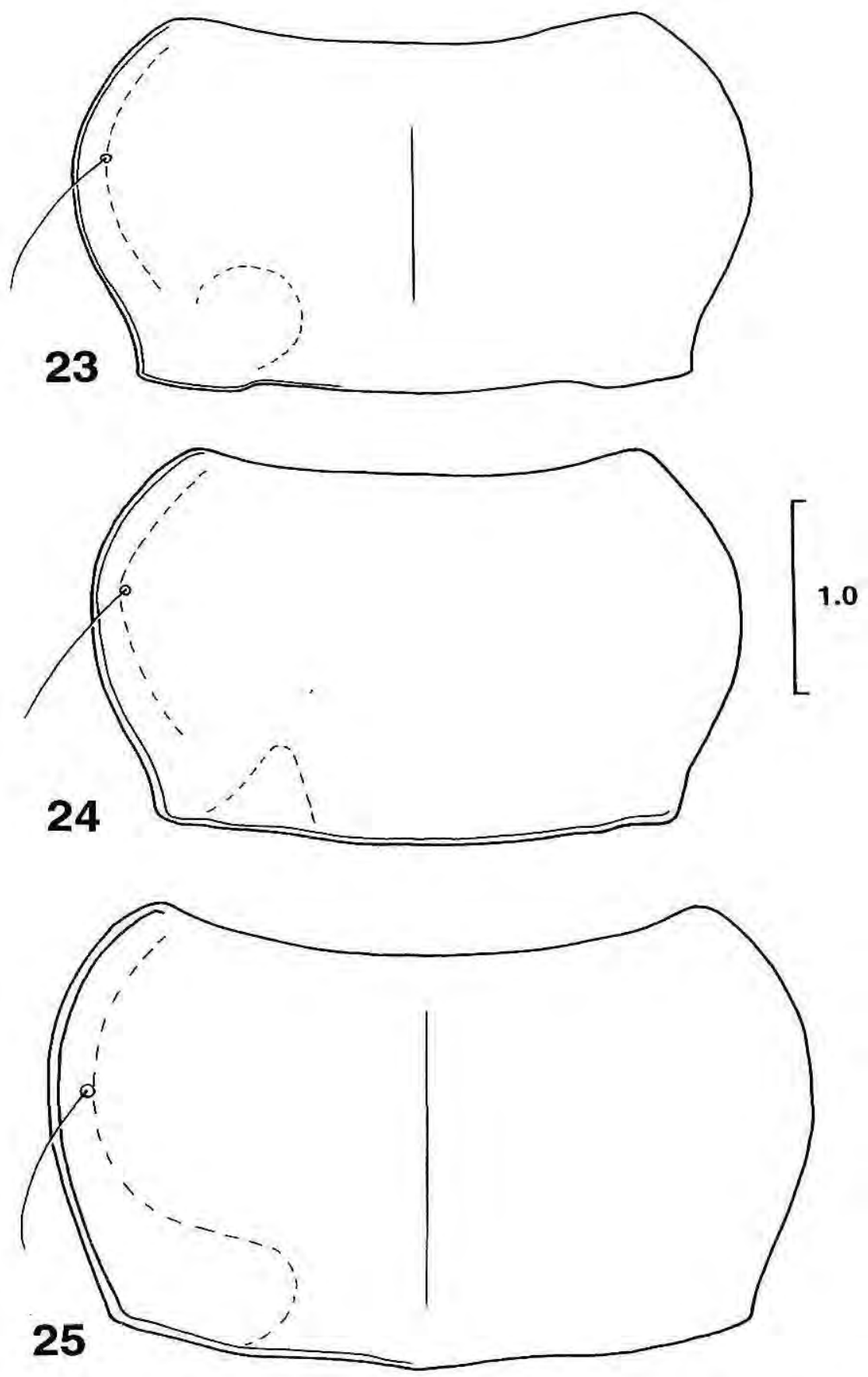

Figures. 23-25. Pronotum. Fig. 23. N. glabrata, Fig. 24. N. aulica, Fig. 25. N. jucunda (scale $1 \mathrm{~mm}$ ). 